\title{
THEORETICAL BACKGROUND OF INTERNAL AND EXTERNAL ENVIRONMENT OF NEGOTIATION
}

\author{
Melinda Timea FÜLÖP ${ }^{1}$ \\ Nicolae $M \breve{A G D A} S^{2}$ \\ George Silviu CORDOȘ
}

\begin{abstract}
Corporate failures and financial scandals are a phenomenon that emerged long before the 21st century. Different scandals around the globe spread over the last decades such as Enron, Parmalat, WorldCom have intrigued the stakeholders to question the roles and efficiency of both auditors and management. To answer this question, the authors conduct qualitative research: the exposure of theoretical background in the field of audit-auditee relationship in the context of corporate governance. Auditor-auditee negotiation concerning difficult client accounting issues involves not only the auditor and the client, but also various other parties on both sides. Moreover, the implications of such a situation have various ramifications that surpass the boundaries of many regulations. The results show that the auditor-auditee relationship is of key importance for the auditing process, also based on the macro and microenvironment of this relationship and the negotiations model that can also have an influence on the matter.
\end{abstract}

Keywords: audit, negotiation, auditor, auditee

Jel classification: M42

\section{Introduction}

One of the significant factors for the financial crisis that occurred at the beginning of the precedent century was either the failure of corporate governance regulations and improper appliance of audit standards and corporate governance codes, or the lack of potential for auditing in reporting problems ahead of the time they go out of auditing process. Analysing how auditing on one hand and corporate governance, on the other hand, failed to play their role is of crucial importance to be able to correct the flaws as soon as possible.

In consequence of this facts, the main objective of our paper is to try to draw a theoretical background of the environmental factors that influence the relationship auditor-auditee in the context of corporate governance. The motivation to conduct a research on this subject is triggered by the fact that auditing as a profession relies on the independence principle (Byrne, 2001; Ruddock et al., 2004) reflected in the end in a reliable auditor's report. But, the relationship developed between audit and auditee before and during the audit process is very complex, the most significant characteristics being the negotiation (Antle \& Nalebuff, 1991; Kennedy, 1992; Pruitt \& Carnevale, 1993; Gibbins et al., 2001; Salterio, 2012).

This paper contributes to the literature in the field of macro and microenvironment of the relationship, taking into consideration first of all, the protectionist relationship, the stewardship

\footnotetext{
${ }^{1}$ Babeș - Bolyai University of Cluj - Napoca, Faculty of Economics and Business Administration, 58 - 60 Th. Mihali Street, Cluj - Napoca 400591, Romania, melinda.fulop@econ.ubbcluj.ro

${ }^{2}$ Babeș - Bolyai University of Cluj - Napoca, Faculty of Economics and Business Administration, 58 - 60 Th. Mihali

Street, Cluj - Napoca 400591, Romania, nicolae.magdas@econ.ubbcluj.ro

${ }^{3}$ Babeș - Bolyai University of Cluj - Napoca, Transylvania Business School, 7 Horea Street, Cluj - Napoca 400591, Romania george.cordos@tbs.ubbcluj.ro

DOI: 10.29302/oeconomica.2019.21.1.3
} 
relationships and last but not list the statutory \& working relationship that contribute to describe the micro and macro environment.

The remainder of this paper presents the methodological aspects followed by revealing the most important elements of the auditor-auditee relationship theoretical background and debates concerning the interaction between them. In the last part of the paper are the conclusions, limits and perspectives for future researches in this challenging and debatable area of knowledge.

\section{Data and Methodology}

To achieve the objective of this paper the research is based on a inductive reasoning (Gray et al., 2007) starting with collecting data about auditor -auditee relationship based on the relevant international literature and the developing a theoretical background as a result of the data analysis with the aim to illustrate a generalizable conjecture out of observations. The approach is from particular to general and data is collected to generate the theoretical background (Saunders et al., 2009; Bryman \& Bell, 2007). The purpose of this process is to contribute to a better understanding the literature in the field as a mandatory step before performing significant research in an area (Boote \& Beile, 2005).

Based on the current published literature, the relationship auditor-auditee can be explained from a micro and macro perspective. The whole phenomenon under study - the relationship auditor-auditee is understood as a complex system that is more than the sum of its parts; the focus is on complex interdependencies and system dynamics that cannot be reduced in any meaningful way to linear, cause and effect relationships and/or a few discrete variables.

\section{Factors influencing auditor-auditee relationships}

The auditor-auditee relationship is a current and very debatable topic of our days. Recent researches show that there are audit firms giving too much importance to their clients and rotate the audit partners before mandatory rotation due to their commercial interests (Chen et al., 2016; Lennox \& Wu, 2016; Stewart et al. 2015). Lennox (2005) recognized that auditor-auditee relationship, will affect audit quality negatively. Their argumentation is based on the probability that the auditor will discover and/or report a problem in the financial statements of the firm is reduced. In line with this, Bruynseels and Cardinaels (2013) consider auditor independence as indicator of audit quality, and it will decline if there exists personal ties between the executive of the auditee and former audit personnel that performed the audit of the company.

Another area of debate for researchers is auditor independence and its influence on audit quality, given the relationship between audit failures and audit-auditee tenure (Sikka et al. 2009; Li, 2009; Daniels \& Booker, 2011; Joe et al., 2011; Al-Thundeibat et al., 2011; Gonthier-Besacier et $a l ., 2016)$. Nevertheless, proof consistent with concerns regarding reduced independence actually gives several legitimacy to criticism of the way the accounting profession developed over time into firms providing broad-based services (Ruddock et al., 2004).

In this part we want to describe the context in which interaction between auditor and auditee takes place. In this sense we identify two dimensions, the internal environment and external environment. Based on the literature we identify the following variables that influence the internal environment: audit opinion, audit work, self-interest, accounting techniques, going concern, expectation gap, dependency and ethical guidance. The external variables that we identify in the literature are as follow: audit regulations, competition, self-regulation and the third parties (banks, creditors, investors, stock exchange, politicians, academics, analysts and others).

The two groups of situational dimensions (internal and external environments) combine to influence the ways auditors, shareholders, management and third parties (bank, creditor, stock exchange, regulators, investors, politician, academics, analysts and others) interact. The structure and process dimensions of interactions can be divided into:

a) Protectionist Relationship: (Auditor - Shareholders) 
b) Stewardship Relationship: (Management - Shareholders)

c) Statutory and Working Relationship: (Auditor-Client)

\section{The structure and process dimensions of interactions}

\section{a.) The protectionist relationship}

This link between the auditor and the shareholders stems from the relationship they have, the auditors being appointed to act to protect their interests in the company. In practice, shareholders are less involved in the audit engagement than the management of the firm, so they are based on the work of the auditor. The protectionist relationship, the interaction between auditors and shareholders, has not yet been debated in financial institutions and markets. But, it is a general agreement that all relevant financial information will be made available and be easily accessed through the Stock Exchange and the Internet for the entities listed on the stock exchange. However, there have been no studies or suggestions on how to make auditors communicate with the shareholders and investors apart from the audit annual report or the audit interim report. Companies faced a difficult task in steering a balanced course between compliance with the complex rules and meeting the legitimate demands of analysts for information.

\section{b.) The stewardship relationships}

The stewardship theory was developed following criticism of the theory of the agency (Davis et al., 1997). The stewardship theory contains a complementary system to that of the Agency's Theory as regards the relationship of the parties involved. The basis for the stewardship theory is the exchange relationship, in this case between a principal (owner) and a steward (administrator). The basic difference between the theory of the agency and the stewardship theory can be seen in the way the administrator/manager behaves. Stewardship theory establishes that managers are handy administrators who are doing good work in the interests of their owners. The desire for promotion, affiliation, achievement and responsibility motivates administrators to focus on long-term collective responsibility, which is why managers will not pursue their own benefits (Fischer 2003).

The premise behind the stewardship theory is that managers are essentially trustworthy in corporate governance. It is very important that managers do not automatically adopt behaviour centred on their own interests but rather focus on the interest of the owners (Solomon, 2007).

The conceptual basis of the theory is related to the elaboration of Theory Y, which was issued by McGregor, which starts from the assumption that managers are rational beings, so there is no need for excessive monitoring of their behaviour as assumed by the Agency Theory (Nicholson \& Kiel 2007). Eliminating the need to monitor manager's results in cost reductions (Donaldson \& Davis, 1994). Management, the owner of the property of owners, will protect and maximize their interests by increasing the company's performance. As a result, the utility of the administrator increases if he decides to work for the development of the company and does not adopt a contrary position, focusing solely on his own benefits. This view is also shared by Goldman and Barlev (1974). However, this moral hazard can be solved by designing, for the manager, incentive contract which are more closely aligned with the interests of the shareholders (e.g., bonus plans to net income). Another option to alleviation of the moral hazard problem is to provide complete public disclosures of the firm's information in order to remove the superior information position of the manager (Shirley-Beaver, 1981).

The stewardship theory considers an important factor in the management structure. The management structure must be composed of internal members of the company because they know the entity's problems and can react with ease. If the management of the entity only includes external members, it is more difficult to react to the entity's problems. Entities from the outside of the entity can track the maximization of the company's performance in the short run as their knowledge of the entity's activity is reduced to the executives coming from within the entity that is experiencing dayto-day problems within the entity (Solomon, 2007). 


\section{c.) The statutory \& working relationship}

This is a legal requirement. All listed companies are required to have their financial statements audited by qualified accountants who must report whether or not the statements show a true and fair view. Then, the owners of the company, investors and other interested parties will draw their own conclusions and act accordingly.

The Auditor-Management relationships include only individuals involved in the preparation of the accounts, planning the audit task and time. All listed companies and other types of companies prescribed in national regulations are required by law to have their accounts audited by auditors. Accounts are presented annually to shareholders and after their approval the financial statements and the audit report are publicly available for other parties like investors and any other party interested in the company activities. Is the company management task to ask for an auditor services and during the audit process to provide to the auditor the required information. This relation should be considered a statutory and in the same time a working relationship (between auditors and their clients): there is a legal requirement and involves formal and informal working rules in preparing the accounts, agreeing about the accounting techniques and the influence of one member on the other. Moreover, it deals with the conflict resolution mechanisms when formal rules or informal influence fails.

The relationship between auditor and auditee involves formal and informal working rules in preparing the accounts, agreeing about the accounting techniques and the influence of one member on the other. Moreover, it deals with the conflict resolution mechanisms when formal rules or informal influence fails.

\section{Macro -microenvironment relationship}

In accordance with the literature, there are several factors that influence the relation between auditor-auditee and their outcome such as independence, the role of regulator's enforcement, voluntary audit partner and audit firm rotation, commercialism, public trust, audit quality. DeAngelo (1981) defined audit quality as the market-assessed joint probability of auditor's ability to detect a misstatement in the clients' accounting system (perceived auditor competence) and reporting the misstatement (perceived auditor independence). So basically, the first step after discovering a certain issue in the financial statements during an audit process is to disclose it, in order for the audit profession to reach its goal. Of course, that disclosure is not sufficient by itself, as the disclosed information must be kept as it is from the moment of its discovery. This is the reason why independence is of such importance, and this is the key to making the difference between appearances and reality as (Ruddock et al., 2004) were saying. None the less, "the auditor is the instigator of most negotiations as the easiest path for the auditor, in line with his client retention, sales of other audit services, reputation within firm and other incentives, as it would be easier to accept the client's initial accounting position except when the auditor feels constrained by another important contextual feature (e.g. an accounting standard that the auditor believes applies to the circumstances but the client does not)".

The relationship auditor-auditee can be explained at a different level, more than in the literature we identify a macro environment relationship and a microenvironment relationship.

- Macro environment relationship

As shown in the figure below, we intensify in the literature three major players in the audit relationships at the macro environment level. 


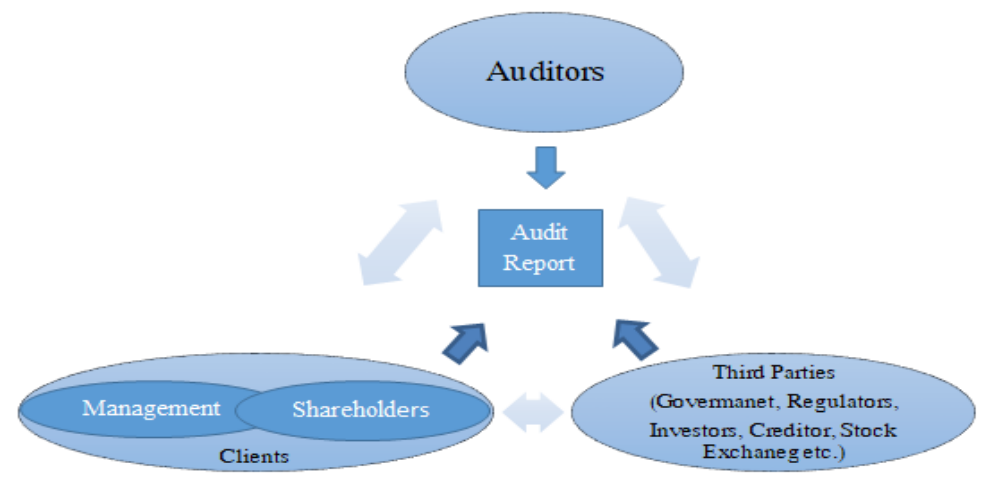

Figure no.1 Macro environment level

Source: Based on: Goldman, A and Barlev, B. (1974), "The Auditor-Firm Conflict of interests: Its Implications for Independence" The Accounting Review, October, pp. 707-718

As we Shown in the figure below, at the microenvironment relationship ar also three main actors: Auditor, Client and Management.

(1)The Auditor-Management relationships include only individuals involved in the preparation of the accounts, planning the audit task and time. The major parties in this relationship are auditors and management. All medium-sized and large limited companies are required by law to have their accounts audited by qualified accountants, i.e. auditors. Accounts are presented annually to shareholders, investors and any other party interested in the company activities.

(2)The role of the auditor in the relationship auditor-shareholders is that the auditor is played by the shareholders to check upon the management and protect them from wrongdoing and frauds.

(3)Management-Shareholders relationship reflects whether the management is taking care of the money of the company's owners, i.e., the shareholders. A general relationship, which has a tendency to embrace all interactions, is the statutory relationships.

- Microenvironment relationship

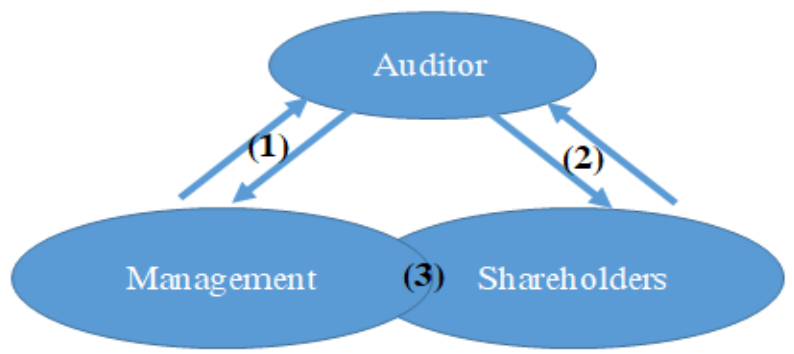

Figure no. 2 Microenvironment level

Source: Based on: Goldman, A and Barlev, B. (1974), "The Auditor-Firm Conflict of interests: Its Implications for Independence" The Accounting Review, October, pp. 707-718

(1) Statutory \& working relationship (between auditors and their clients) This is a legal requirement and involves formal and informal working rules in preparing the accounts, agreeing about the accounting techniques and the influence of one member on the other. Moreover, it deals with the conflict resolution mechanisms when formal rules or informal influence fails. This study focuses on statutory and working relationships.

(2) Protectionist relationship (between auditors and shareholders) This relationship derives from the fact the auditors are theoretically agreed by the shareholders to protect their interests in the company, i.e., Auditors are paid by the shareholders to check upon the management and protect them from wrongdoing and frauds. In practice, the shareholders are less involved with auditors than the management. 
(3) Stewardship relationship (between management and shareholders) is explaining in the literature between the agency theory.

Moreover, there are various sources of influence on the audit relationships. Some potential sources of factors that we identify and can affect the auditor-client relationships are audit report, selfinterest, regulations, accounting techniques, non-audit services and competition.

\section{Conclusion}

Now, audit becomes a complex, interactive and judgmental process, which requires a high level of technical knowledge, integrity and interpersonal skills from the audit engagement partners. As a consequence, the audit profession continues to face multiple, complex challenges. But, the investors and markets rely on the ability of the profession to overcome them. As it has been in the past, the profession will do so - meeting not only the known challenges but also the unknown as they unfold.

The paper reached its objective by outlining the recent developments and academic debates concerning the auditor-auditee relationship. For this, a qualitative research based on a structured literature review was conducted. Our starting point was to set-up the context of audit and auditorauditee relationship. Corporate governance context highlight the significant responsibilities of an auditor for protecting the interest of shareholders. The audit serves as a "monitoring device" and is thus part of the corporate governance mosaic(Cohen et all, 2002).

The relation developed between audit and auditee before and during the audit process is very complex, the most significant characteristics being the negotiation. For this reason, the study appeals at the classic model of auditor-auditee negotiation developed by Gibbins et al. (2001) and others.Moreover the auditor-auditee relationship is then explored at the macro and micro level and develop the roles of each parties involved.

Overall, the paper started from the study of literature being a qualitative theoretical paper that highlights the importance of the relationship auditor-auditee in the context of corporate governance. This topic involves a number of research perspectives such as analysis more detailed the concept of auditor-auditee and the relationship between this actors at micro and macro level in the context of corporate governance in different cultural context like for example in the case of countries with an emerging economies and a centralised economy past.

\section{References}

1. Al-Thuneibat, A.A., Al Issa, R.T., Baker,. R.A. (2011): Do audit tenure and firm size contribute to audit quality? Empirical evidence from Jordan, Managerial Auditing Journal, Vol. 26, No. 4, pp. 317-334.

2. Antle, R., \& Nalebuff, B. (1991). Conservatism and auditor-client negotiations. Journal of Accounting Research, 29, 31-54.

3. Belcoucif, A.,(2008), "Auditor-client relationships: an assessment of relationship quality". Available from OpenAIR@RGU. [online].Available from: http://openair.rgu.ac.uk

4. Boote, D. N., \& Beile, P. (2005). Scholars before researchers: On the centrality of the dissertation literature review in research preparation. Educational Researcher, 34(6), 3-15.

5. Bruynseels, L., \& Cardinaels, E. (2013). The audit committee: Management watchdog or personal friend of the CEO? The accounting review, 89(1), 113-145.

6. Bryman, A. \& Bell, E. (2007). Business Research Methods. 2nd edition. New York, USA: Oxford University Press 2007.

7. Byrne, P. (2001). Auditor independence: an update. ACCA - the global body for professional accountants, http://www.accaglobal.com/archive/2888864/31241.

8. Chen, F., Peng, S., Xue, S., Yang, Z., \& Ye, F. (2016). Do Audit Clients Successfully Engage in Opinion Shopping? Partner-Level Evidence. Journal of Accounting Research, 54(1), 79-112. 
9. Cohen, J., Krishnamoorthy, G. and Wright, A. M. (2002), Corporate Governance and the Audit Process*. Contemporary Accounting Research, 19: 573-594. doi:10.1506/983M-EPXG-4Y0RJ9YK.

10. Daniels, B., Booker, Q. (2011): The Effects of Audit Firm Rotation on Perceived Auditor Independence and Audit Quality, Research in Accounting Regulation, Vol. 23, Issue 1, pp 7882.

11. Davis, H. J., Schoorman, D. and Donaldson, L. (1997) 'Toward a stewardship Theory of Management' Academy of Management Review, 22(1): 20-47.

12. DeANGELO, L. (1981), "Auditor independence.Tow balling', and disclosure regulation", Journal of Accounting \& Economics, Vol.3, No.2, pp.113-127.

13. Donaldson, L. and Davis, J. H. (1994) 'Boards and company Performance- Research Challenges the Conventional Wisdom', Corporate Governance: An International Review, 2: 151-60.

14. Gibbins, M., S. Salterio, and A. Webb. 2001. Evidence about auditor-client management negotiation concerning client's financial reporting. Journal of Accounting Research 39 (3): 535-563.

15. Goldman, A and Barlev, B. (1974), "The Auditor-Firm Conflict of interests: Its Implications for Independence" The Accounting Review, October, pp. 707-718.

16. Gonthier-Besacier, N., Hottegrindre, G., Fine-Falcy, S. (2016): Audit Quality Perception: Beyond the 'Role-Perception Gap', International Journal of Auditing, Vol. 20, pp. 186-201.

17. Gray, P., Williamson, J.B., Karp, D.A., Dalphin, J.R. (2007): The Research Imagination - an introduction to qualitative and quantitative methods, Cambridge University Press, ISBN-13 978-0-511-33417-7, Cambridge, pp. 480.

18. Joe, J., Wright, A., Wright, S. (2011): The Impact of Client and Misstatement Characteristics on the Disposition of Proposed Audit Adjustments, Auditing: A Journal of Practice \& Theory, Vol. 30, No. 2, pp. 103-124.

19. Kennedy, G. (1992). The perfect negotiation. New York: Random House.

20. Lennox, C. (2005). Audit quality and executive officers' affiliations with CPA firms. Journal of accounting and economics, 39(2), 201-231.

21. Lennox, C. S., \& Wu, X. (2016). A Review of the Literature on Audit Partners.

22. Li, C. (2009): Does Client Importance Affect Auditor Independence at the Office Level? Empirical Evidence from Going-Concern Opinions, Contemporary Accounting Research, Vol. 26, No. 1, pp. 201-230.

23. Nicholson, G. J. and Kiel, G. C. (2007) 'Can Directors Impact Performance? A case-based test of three theories of corporate governance', Journal Compilation, Blackwell publishing, 15(4): 585-608.

24. Pruitt, D. G., and P. J. D. Carnevale. 1993. Negotiation in Social Conflict. Buckingham, U.K.: Open University Press.

25. Ruddock, C Sherwood K, Taylor S (2004), Non-Audit Services and Earnings Management: Is Auditor Independence Impaired?

26. Salterio S.E. (2012), Fifteen years in the trenches: Auditor-client negotiations exposed and explored, Accounting and Finance 52 (2012 Suppl.) 233-286.

27. Saunders M., Lewis P. \& Tornhill A. (2009). Research Methods for Business. 5nd edition. England: Pearson Education Limited.

28. SHIRLEY-BEAVER, M. (1981), "Is There More Than One Accounting Profession?", Annual Accounting Review, Vol.3, pp.223-240.

29. Sikka, P., Filling, S., Liew, P. (2009): The audit crunch: reforming audit, Managerial Auditing Journal, Vol. 24, No. 2, pp. 135-155.

30. Solomon J.(2007), Corporate Governance and accountability, Second Edition, JohnWiley\&Sons, Ltd,England. 
31. Stewart, J., Kent, P., \& Routledge, J. (2015). The association between audit partner rotation and audit fees: Empirical evidence from the Australian market. Auditing: A Journal of Practice \& Theory, 35(1), 181-197. 